\title{
APLIKASI MODEL LOGIT UNTUK MENGETAHUI FAKTOR-FAKTOR YANG MEMPENGARUHI PREDIKSI PERINGKAT OBLIGASI PERBANKAN YANG TERDAFTAR DI BURSA EFEK INDONESIA
}

\author{
Andre Kussuma Adiputra \\ Fakultas Ilmu Sosial Dan Ekonomi, Universitas Respati Yogyakarta, Jl. Laksda Adisucipto Km. \\ 6,3 Depok, Yogyakarta; \\ Email:andre_adiputra@gmail.com
}

\begin{abstract}
Abstrak
Obligasi merupakan surat utang jangka menengah-panjang yang dapat dipindahtangankan yang berisi janji dari pihak yang menerbitkan untuk membayar imbalan berupa bunga pada periode tertentu dan melunasi pokok utang pada waktu yang telah ditentukan kepada pihak pembeli obligasi tersebut. Investor dapat memperjualbelikan Obligasi yang dimilikinya sebelum jatuh tempo dan memperdagangkannya di pasar modal atau yang juga dikenal sebagai Bursa Efek Indonesia.Salah satu informasi yang seringkali dipertimbangkan investor dalam mengambil keputusan membeli obligasi perusahaan adalah Peringkat Obligasi.

Secara umum peringkat obligasi dapat dibagi menjadi investment grade dan non investment grade.Penelitian ini berusaha untuk mengetahui faktor-faktor yang mempengaruhi peringkat Obligasi pada sektor Perbankan yang terdaftar di Bursa Efek Indonesia.

Alat analisis yang digunakan adalah model Logit. Model Logistik digunakan dikarenakan variabel independen dalam penelitian ini adalah variabel binary. Penggunaan dua alat analisis nantinya akan dapat mengetahui kemampuan alat analisis tersebut dalam memprediksi peringkat obligasi.

Hasil analisis menunjukkan bahwa Model Logit yang digunakan memberikan hasil yang memuaskan dalam mengestimasi model yang ada.Lebih lanjut dari hasil peneltian bahwa obligasi dari prusahaan dengan rasio profitabiltas dan ukuran perusahaan yang tinggi memiliki peluang masuk kategori investmen grade yang lebih besar. Sedangkan peluang obligasi perusahaan masuk kategori investment grade tidak dipengaruhi oleh pertumbuhan perusahaan dan likuiditas
\end{abstract}

Kata Kunci : Obligasi, Peringkat Obligasi, Logit Model, Probit Model.

\section{PENDAHULUAN}

\subsection{Latar Belakang Masalah}

Obligasi merupakan surat utang jangka menengah-panjang yang dapat dipindahtangankan yang berisi janji dari pihak yang menerbitkan untuk membayar imbalan berupa bunga pada periode tertentu dan melunasi pokok utang pada waktu yang telah ditentukan kepada pihak pembeli obligasi tersebut (Hartono, 2014). Penerbitan obligasi dilakukan oleh perusahaan yang membutuhkan dana baik untuk keperluan pengembangan bisnisnya atau untuk memenuhi kebutuhan keuangan lainnya (Hartono, 2014).

Investor dapat memperjualbelikan Obligasi yang dimilikinya sebelum jatuh tempo dan memperdagangkannya di pasar modal atau yang juga dikenal sebagai 
Bursa Efek Indonesia.Investor dalam mengambil keputusan pembelian obligasi suatu perusahaan harus memperhatikan banyak hal.Salah satu informasi yang seringkali dipertimbangkan investor dalam mengambil keputusan membeli obligasi perusahaan adalah Peringkat Obligasi.Peringkat Obligasi memberikan informasi tentang probabilitas kegagalan utang suatu perusahaan. Sehingga dengan melihat peringkat obligasi suatu perusahaan investor dapat memperkirakan besarnya resiko yang akan dihadapinya ketika akan memberikan pinjaman dana ke suatu perusahaan atau akan membeli obligasi di pasar sekunder.

$$
\text { Peringkat obligasi }
$$

dikeluarkan oleh agen pemeringkat obligasi.Agen pemeringkat obligasi adalah lembaga independen yang memberikan informasi pemeringkatan skala resiko sebagai petunjuk sejauh mana keamanan suatu obligasi bagi investor.Keamanan tersebut ditunjukkan oleh kemampuan suatu perusahaan dalam membayar bunga dan melunasi pokok pinjaman.
Informasi dari agen pemeringkat obligasi ini tentunya akan sangat membantu investor dalam mengambil keputusan investasinya (Hartono, 2014).

Informasi yang terkandung dalam rating akan menunjukkan sejauh mana kemampuan suatu perusahaan untuk membayar kewajibannya atas dana yang diinvestasikan oleh investor. Perusahaan yang memiliki rating tinggi tentunya dianggap investor akan memberikan rasa aman yang lebih baik dibandingkan perusahaan yang mempunyai rating obligasi yang rendah.Rating suatu obligasi dapat dibedakan menjadi dua, yaitu obligasi dan dalam kategori investment grade dan non investment grade. Perusahaan tentunya akan berusaha agar obligasi yang dikeluarkannya masuk dalam golongan investment grade, sehingga obligasi akan banyak diminati investor dan perusahaan tidak perlu memberikan return yang terlalu tinggi yang nantinya akan dapat membebani keuangan perusahaan.

Dalam kerangka pemikiran tersebut, penelitian ini disusun. 
Penelitian ini akan berusaha menggunakan faktor-faktor yang menentukan faktor-faktor yang telah ditentukan diatas akan menentukan suatu obligasi masuk dalam peringkat investment grade atau dalam peringkat non-investment grade. Model penelitian yang disusun menempatkan variabel diskrit sebagai variabel independen, untuk itu aplikasi model Logit dan Probit akan digunakan sebagai alat analisis. Sedangkan data penelitian ini akan menggunakan data obligasi dari perusahaan di sektor perbankan yang memperdagangkan obligasinya di Bursa Efek Indonesia.

dilakukan analisis dengan metode logit dan probit untuk dapat menentukan faktor-faktor yang mempengaruhi peringkat obligasi perbankan yang terdaftar di Bursa Efek Indonesia.

\subsection{Perumusan masalah}

Sesuai dengan hubungan yang telah dibatasi maka dibangun rumusan masalah sebagai berikut:

1. Apakah terdapat pengaruh antara pertumbuhan perusahaan terhadap

\subsection{Identifikasi Masalah}

Dalam penelitian ini faktorfaktor yang mempengaruhi prediksi peringkat obligasi perbankan yang terdaftar di Bursa Efek Indonesia dirumuskan sebagai berikut (Setyaningtyas, 2014):

1. Pertumbuhan perusahaan

2. Ukuran perusahaan

3. Profitabilitas perusahaan

4. Likuiditas perusahaan.

\subsection{Pembatasan Masalah}

Berdasarkan identifikasi praktek prediksi peringkat obligasi?

2. Apakah terdapat pengaruh antara ukuran perusahaan terhadap prediksi peringkat obligasi?

3. Apakah terdapat pengaruh antara profitabilitas terhadap praktek prediksi peringkat obligasi

4. Apakah terdapat pengaruh antara likuiditas terhadap praktek prediksi peringkat obligasi.

masalah maka penelitian ini 


\subsection{Manfaat Penelitian}

Kajian ini diharapkan dapat memberikan masukan bagi Perusahaan ataupun Investor. Bagi perusahan yang akan mengerluarkan Obligasi dapat memperhatikan faktor-faktor yang mempengaruhi peringkat obligasi tersebut, sehingga dapat memprediksi peringkat obligasi yang akan dikeluarkan. Bagi Investor penelitian juga membantu melakukan prediksi peringkat obligasi dengan memperhatikan faktor-faktor yang mempengaruhinya.Sehingga investor dapat melakukan invetasi dengan lebih baik.dan tepat sasaran.

\section{TINJAUAN PUSTAKA}

\subsection{Teori Sinyal}

Teori sinyal menunjukkan adanya hubungan asimetri antara manajemen dengan berbagai pihak yang berkepentingan terhadap informasi perusahaan (Setyaningsih, 2014).Asimetri informasi terjadi dikarenakan salah satu pihak memiliki informasi yang lebih baik dibanding dengan pihak lainnya. Manajemen selaku pihak intern perusahaan memiliki informasi yang lebih baik dibanding dengan pihak yang lain.

Sebelum memutuskan untuk berinvestasi pada obligasi suatu perusahaan, pihak eksternal perusahaan seperti calon investor tentu sangat membutuhkan informasi tentang kondisi obligasi. Untuk itu dengan teori sinyal diharapkan manajemen memberikan memberikan sinyal berupa informasi mengenai kualitas atau kondisi obligasi, apakah obligasi berpotensi gagal bayar atau tidak. Salah satu sinyal tersebut ditunjukkan dengan peringkat obligasi.

\subsection{Pemeringkatan Obligasi}


Peringkat obligasi merupakan

opini dari lembaga pemeringkat serta sumber informatif bagi pemodal atas risiko obligasi yang diperdagangkan (Berdasarkan Keputusan BAPEPAM dan Lembaga keuangan Kep151/BL/2009).Informasi peringkat tersebut diharapkan dapat membantu investor dalam mengambil keputusan investasi. Sedangkan bagi emiten, peringkat bermanfaatuntuk mengetahui struktur obligasi dan mengetahui posisi kinerjanya dibanding perusahaan lain (Setyaningsih, 2014).

Berdasarkan Keputusan Ketua BAPEPAM dan Lembaga Keuangan Nomor: 135/BL/2006 Tentang "Pemeringkatan Atas Efek Bersifat Utang" menyatakan bahwa emiten yang akan menerbitkan obligasi wajib memperoleh hasil pemeringkatan obligasi. Hasil pemeringkatan tersebut diterbitkan oleh lembaga pemeringkat yang telah mendapat izin usaha sebagai lembaga pemeringkat dari Badan Pengawas Pasar Modal dan Lembaga Keuangan.

Lembaga pemeringkat memberikan peringkat obligasi setiap satu tahun sekali selama obligasi tersebut belum lunas.Pemeringkatan antara perusahaan satu dan lainnya tidak dilakukan serentak seluruh perusahaan melainkan secara terpisah sesuai dengan perjanjian yang telah disepakati masing-masing perusahaan dengan lembaga rating. Lama pengumpulan data dan analisis memakan waktu lebih dari 1 bulan (Hartono, 2014).

\subsection{Pemeringkat Efek Indonesia (PEFINDO)}

PT PEFINDO didirikan di Jakarta pada tanggal 21 Desember 1993 atas ijin Badan Pengawas Pasar Modal (BAPEPAM) dan Bank Indonesia.Pada tanggal 13 Agustus 1994, PT PEFINDO memperoleh lisensi dari BAPEPAM (No.39/PMPI/1994) dan menjadi salah satu institusi pendukung di pasar modal Indonesia.Lembaga ini berafiliasi dengan Standard \& Poor's, yang merupakan agen pemeringkat internasional.

Proses pemeringkatan dilakukan dengan menggunakan analisis kinerja keuangan, industri, dan non keuangan (bisnis) 
(PEFINDO, 2009). Ada beberapa hal yang perlu diperhatikan dalam analisis obligasi, yaitu (Ninik, 2013):

1. Kinerja Industri :Mencakup persaingan industri, prospek dan pangsa pasar, ketersediaan bahan baku, struktur industri, pengaruh kebijakan pemerintah, dan kebijakan ekonomi lainnya.

2. Kinerja Keuangan :Meliputi aspek kualitas aset, rasio profitabilitas, pengelolaan aset dan pasiva, rasio kecukupan modal, tingkat pengelolaan utang, dan rasio kecukupan pembayaran bunga.

3. Kinerja Non Keuangan:

Terdiri dari aspek manajemen, reputasi perusahaan, serta perjanjian indenture (meliputi sinking fund, debt test, dividend test, merger, dan sale of asset).
Selain itu untuk kelengkapan prosedur pemeringkatan, beberapa data yang diperlukan antara lain (Ninik, 2013):

a. Akte perusahaan atau izin perusahaan.

b. Laporan keuangan yang diaudit selama 5 tahun terakhir.

c. Proyeksi laporan keuangan untuk 3 tahun ke depan atau selama masa penerbitan surat utang tersebut.

d. Info memo tentang proses penerbitan surat utang.

e. Informasi pihak ketiga (pemberi garansi atau bank garansi).

f. Daftar pemegang saham selama lima tahun terakhir.

g. Daftar riwayat hidup 
komisaris/manaje

men perusahaan.

h. Struktur

organisasi

perusahaan dan

keterangan detail

tugas dan

tanggung jawab.

i. Informasi tentang grup, afiliasi, dan

holding dari

perusahaan.

Setelah selesai melakukan analisis, tim analis kemudian membentuk komite rating untuk memberikan hasil peringkat akhir pada obligasi perusahaan. Peringkat akhir yang diperoleh berdasarkan suara mayoritas dari anggota komite rating.

Bagi perusahaan yang setuju, peringkat akan dipublikasikan pada website PEFINDO. Berdasarkan Keputusan Ketua BAPEPAM-LK Nomor: KEP-156/BL/2009 tentang "Publikasi oleh Perusahaan Pemeringkat Efek" menyebutkan bahwa Publikasi tersebut wajib diselesaikan paling lambat 2 (dua) hari kerja setelah pemeringkatan berakhir.
PEFINDO selaku lembaga pemeringkat juga melakukan monitoring atas hasil peringkat yang telah dipublikasikan.Hal ini untuk menjaga agar informasi atas peringkat yang diberikan relevan dan akurat.Apabila selama pemantauan berkala ternyata kinerja perusahaan memburuk maka agen pemeringkat dapat menurunkan rating tersebut.Begitu juga sebaliknya apabila kinerja perusahaan membaik maka lembaga pemeringkat dapat menaikkan rating perusahaan (Ninik, 2013).

Suatu rating terdiri dari 2 bagian Rating dan Outlook. Rating adalah kemampuan membayar hutang sedangkan Outlook adalah pandangan dari perusahaan pemeringkat apakah Rating akan naik, turun atau tetap pada periode penilaian berikutnya. Rating sendiri terdiri dari 2 yaitu 3 huruf yang disertai dengan tanda atau angka tergantung perusahaan pemeringkat.Rating dapat dikelompokkan menjadi Invesment Grade dan Non Investment Grade. Sebagai contoh urutan dari yang 
paling tinggi hingga paling rendah secara umum adalah sebagai berikut

- Investment Grade

a) AAA atau Aaa

b) $\mathrm{AA}+, \mathrm{AA}$ dan $\mathrm{AA}-$ atau Aa1, Aa2 dan Aa3

c) A+, A, dan A- atau A1, A2 dan A3

d) $\mathrm{BBB}+, \mathrm{BBB}$ dan BBB- atau Baa1, Baa2 dan Baa3

- Non Investment Grade (junk Bond) dengan rating di bawah BBB atau Baa

a) $\mathrm{BB}+, \mathrm{BB}$ dan $\mathrm{BB}-$ atau Ba1, Ba2, dan $\mathrm{Ba} 3$

b) $\mathrm{B}+, \mathrm{B}$ dan $\mathrm{B}-$ atau $\mathrm{B} 1$, B2 dan B3

c) $\mathrm{CCC}+, \mathrm{CCC}$ dan CCC- atau Caal, $\mathrm{Caa} 2$, dan $\mathrm{Caa} 3$

d) $\mathrm{CC}+, \mathrm{CC}$ dan $\mathrm{CC}-$ atau Ca11, Ca2 dan $\mathrm{Ca} 3$

e) $\mathrm{C}+, \mathrm{C}$ dan $\mathrm{C}-$ atau $\mathrm{C} 1$, $\mathrm{C} 2$ dan $\mathrm{C} 3$

f) Default

Investment Grade adalah kategori bahwa suatu perusahaan atau negara dianggap memiliki kemampuan yang cukup dalam melunasi hutangnya.Sehingga bagi investor yang mencari investasi yang aman, umumnya mereka memilih rating Investment Grade. Sepengetahuan penulis, ada perusahaan yang menerapkan screening yang lebih mendalam seperti harus BUMN atau kalaupun investment Grade minimal A. Rating BBB dianggap masih belum aman.

Non Investment Grade adalah kategori bahwa suatu perusahaan atau negara dianggap memiliki kemampuan yang meragukan dalam memenuhi kewajibannya.Perusahaan yang masuk kategori ini biasanya cenderung sulit memperoleh pendanaan.Supaya bisa berhasil umumnya mereka memberikan kupon atau imbal hasil yang tinggi sehingga disebut juga dengan High Yield Bond.Investor yang memilih jenis obligasi ini biasanya cenderung memiliki sifat spekulatif. Sebab jika ternyata perusahaan berkomitmen melunasi seluruh kewajibannya, imbal hasil yang diterima bisa sangat tinggi. 
growth atau pertumbuhan perusahaan.

2. Ukuran Perusahaan ;Ukuran perusahaan menunjukkan tingkat besar atau kecilnya

\section{METODE PENELITIAN}

\subsection{Variabel Dependen (Y)}

Variabel dependen dalam penelitian ini adalah peringkat obligasi. Variabel ini dilihat berdasarkan peringkat yang dikeluarkan oleg PEFINDO yang secara umum terbagi menjadi dua yaitu :Investment grade (AAA, AA, $\mathrm{A}, \mathrm{BBB})$ dan Non investment grade (BB, B, CCC, D)

\subsection{Variabel Independen (X)}

Variabel bebas yang mempengaruhi atau menjadi sebab perubahan timbulnya variabel dependen yang digunakan dalam penelitian ini adalah

1. Pertumbuhan Perusahaan : Pertumbuhan perusahaan yang baik akan memberikan peringkat obligasi yang baik pula. Investor dalam memilih investasi terhadap obligasi akan melihat pengaruh suatu perusahaan yang dapat didasarkan pada total aktiva, penjualan, atau ekuitas. Hasil logaritma dari aktiva, penjualan, atau ekuitas tersebut mencerminkan ukuran suatu perusahaan. Proksi size yang digunakan dalam penelitian ini berdasarkan pada total aktiva karena lebih mencerminkan kekayaan perusahaan secara menyeluruh

3. Profitabilitas ; Profitabilitas adalah rasio yang digunakan untuk mengukur keberhasilan perusahaan dalam memperoleh keuntungan pada tingkat penjualan, asset dan modal yang ada.

4. Likuiditas :Likuiditas merupakan kemampuan perusahaan dalam melunasi kewajiban jangka pendek perusahaan. Variabel likuiditas dalam penelitian ini 
diproksikan dengan current ratio (CR). Menurut Luciana Spica\&Vieka

perusahaan yang mampu melunasi kewajiban tepat waktu adalah perusahaan yang likuid dan mempunyai aktiva lancar lebih besar daripada utang lancar. Current ratio (CR) merupakan perbandingan antara aktiva lancar dan utang lancar.

\subsection{Jenis dan Sumber Data}

Data yang digunakan dalam penelitian ini adalah data sekunder, yang diperoleh dari Indonesia Bond Market, database laporan keuangan yang tersedia di BEI dan ICMD (Indonesia Capital Market Directory).

\subsection{Metode Analisis}

Model dengan sifat kualitatif pada variabel dependennya disebut juga binary/dichotomous adalah model probit.Model probit dalam penelitian ini menggunakan notasi 1 (satu) dan 0 (nol).Angka satu untuk Obligasi dalam kategori Invesment Grade dan angka nol untuk obligasi kategori Non Invesment Grade.

\section{Linier Probaility Model (LPM).}

Sebelum menjelaskan lebih lanjut tentang model probit akan dijelaskan teori yang mendasarinya (Gujarati, 2003) .

$$
Y_{t}=\beta_{1}+\beta_{2} X_{t}+u_{t}
$$

Dimana Yi adalah variabel kualitatif dan $\mathrm{Xi}$ adalah variabel independennya. Model LPM yang digunakan adalah :

$$
E\left(Y_{t} I X_{t}\right)=\beta_{1}+\beta_{2} X_{t}
$$

Dimana $\mathrm{E}(\mathrm{Yt}$ I Xt) adalah ekspektasi terjadi Yi pada saat Xi. Dengan asumsi bahwa Pi adalah ekspektasi $\mathrm{Yi}=1$ (kejadian berhasil) dan 1-Pi adalah ekspektasi Y1 $=0$ (kejadian tidak berhasil) maka dengan menggunakan teori kemungkinan sederhana dimana $\mathrm{Pi}+(1-\mathrm{Pi})=1$, dapat ditulis sebagai berikut :

$$
E\left(Y_{t}\right)=0\left(1-P_{t}\right)+1\left(P_{t}\right)=P_{t}
$$

maka jika digabungkan akan diperoleh :

$$
E\left(Y_{t} I X_{t}\right)=\beta_{1}+\beta_{2} X_{t}=P_{t}
$$

Karena $\mathrm{Pi}$ adalah nilai dari probabilitas maka akan berada pada lingkup $0 \leq E\left(Y_{t} I X_{t}\right) \leq 1$. Sehingga dapat ditarik kesimpulan dari LPM adalah tidak terlalu jauh berbeda 
dengan OLS biasa.Bariabel dependen binary dapat diregress dengan metode OLS. Namun karena hubungan Yi dengan $\mathrm{Xi}$ adalah linear maka nilai Yi sangat tergantung dari nilai Xi akan berada diluar range 0 sampai dengan 1. Hal ini menjadikan LPM tidak terlalu baik.Untuk mengatasi hal tersebut maka digunakan Cumulative Distribution Function $(C D F)$.Model CDF yang sifatnya random ini dibagi menjadi dua yaitu logit dan probit.

\section{Model Logit}

Pada model logit hubungan Pi dan Xi tidak lagi linear. Persamaan yang digunakan adalah (Gujarati, 2003)

$$
P_{t}=\left(E=1 I X_{t}\right)=
$$$$
\frac{1}{1+e^{-\left(\beta_{1}+\beta_{2} X_{t}\right)}} \text { dapat ditulis } P t=
$$$$
\frac{1}{1+e^{-Z}}=\frac{e^{Z t}}{1+e^{Z t}}
$$

Dimana $: Z_{t}=\beta_{1}+\beta_{2} X_{t}$

Dari persamaan diatas dapat dibuat $(1-\mathrm{Pi})$ :

$$
1-P_{t}=1-\frac{e^{Z t}}{1+e^{Z t}}=\frac{1}{1+e^{Z t}}
$$

Sehingga apabila dibandingkan kedua persamaan akan diperoleh persamaan sebagai berikut :

$$
\frac{P t}{1-P t}=e^{Z t}
$$

Dimana itu adalah odds ratio, yaitu probailitas terjadinya kejadian sukses (satu). Kemudian untuk memperoleh Model Logit akan diperoleh nilai Zt itu sendiri seperti dalam persamaan dibawah ini :

$$
L t=\ln \left(\frac{P t}{1-P t}\right)=Z t=\beta_{1}+\beta_{2} X_{t}
$$

Dimana L adalah log natural dari odds ratio.

\section{Pengujian Hipotesis}

Untuk memeriksa peranan variabel-variabel penjelas $(\mathrm{x})$ dalam model, dilakukan pengujian terhadap parameter model $(\beta)$. Pengujian secara simultan dilakukan menggunakan uji G. Statistik uji G adalah uji rasio kemungkinan (likelihood ratio test) yang digunakan untuk menguji peranan variabel penjelas di dalam model secara bersama-sama. Rumus umum uji $\mathrm{G}$ untuk menguji hipotesis(Gujarati, 2003):

$\mathrm{H} 0: \beta 1=\beta 2=\ldots=\beta \mathrm{k}=0$

H1 : minimal ada satu $\beta 1$ yang tidak sama dengan 0 . 
Rumus umum uji G :

G

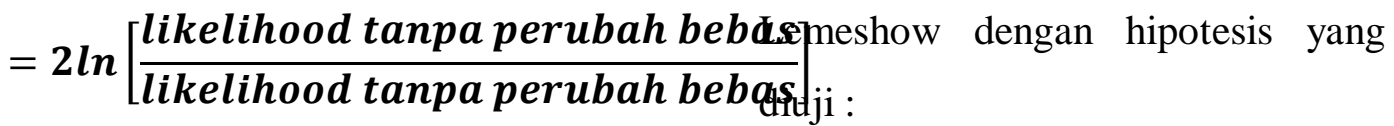

Statistik G secara teoritis mengikuti sebaran $\chi^{2}$ dengan derajat bebas $\mathrm{k}$. Kriteria keputusan yang diambil yaitu menolak $\mathrm{H} 0$ bila $\mathrm{G}$ hitung $>\chi^{2} \alpha(\mathrm{k})$.

Uji Wald digunakan untuk menguji parameter $\beta$ i secara parsial. Hipotesis yang diuji adalah :

$\mathrm{HO}: \beta \mathrm{i}=0$

$\mathrm{H} 1: \beta \mathrm{i} \neq 0$

Formula untuk statistik Wald adalah

$$
W=\frac{\beta_{i}}{S E\left(\hat{\beta}_{i}\right)}
$$

Secara teori statistik uji Wald mengikuti sebaran normal baku jika HO benar. Kreiteria keputusan adalah $\mathrm{H} 0$ ditolak jika IWI $>\mathrm{Z}_{\alpha / 2}$.

Goodness of fit adalah suatu alat statistik yang digunakan untuk pengujian kebaikan atau kecocokan model yang dipostulatkan dibandingkan dengan data yang diamati. Pengepasan dikatakan baik jika ada kesesuaian antara model dengan data yang diamati. Metode yang digunakan untuk goodness of fit pada data kategorik adalah metode Pearson, Deviance dan HosmerH0 : Model yang dipostulatkan layak

H1 : Model yang dipotulatkan tidak layak.

\section{Interpertasi Hasil Regresi}

Interpretasi regresi logistic menggunakan odds ratio $(\psi)$ atau kemungkinan yang menjelaskan berapa lipat kenaikkan atau penurunan peluang $\mathrm{Y}=1$, jika nilai variabel penjelas $(\mathrm{x})$ berubah sebesar nilai tertentu. Nilai Odds ratio selalu positif. Hubungan antara odds ratio $(\psi)$ dan parameter model $(\beta)$ adalah (Gujarati, 2003):

$$
\omega_{a b}=e^{\beta(b-a)}
$$

Jika $\psi a b$ adalah odds ratio antara obyek dengan $\mathrm{X}=\mathrm{b}$ terhadap obyek dengan nila $\mathrm{X}=\mathrm{a}$ adalah :

Jika $\beta>0$ maka odds ratio akan $\psi>$ 1

Jika $\beta=0$ maka odds ratio akan $\psi=$ 1 
Jika $\beta<0$ maka odds ratio akan $\psi<$ 1

\section{HASIL DAN PEMBAHASAN}

\subsection{Deskripsi Obyek Penelitian}

Obyek penelitian yang digunakan adalah perusahaan dari sector perbankan yang menerbitkan obligasi untuk periode 2007 sampai dengan 2012 dan memenuhi kriteria yang telah ditetapkan dalam purposive sampling. Kriteria yang dipertimbangkan dalam pengambilan sampel penelitian ini adalah sebagai berikut:

1. Perusahaan menerbitkan obligasi selama periode 2007 2012

2. Obligasi diperingkat oleh Pefindo

3. Perusahaan menerbitkan Laporan Keuangan yang telah diaudit selama periode 2007 2012.

Dari hasil pengambilan sampel diperoleh 14 perusahaan perbankan memenuhi kriteria selama 6 tahun sehingga jumlah data yang ada sebanyak 84 data.

\subsection{Statistik Deskriptif}

Analisis statistikdeskriptif yang digunakan dalam penelitian ini untuk variabel skala rasio adalah maksimum, minimum, angka ratarata (mean), dan standar deviasi. Sedangkan variabel dummy disajikan dalam bentuk frekwensi.Berikut ini dijelaskan statisti deskriptif dari data penelitian yang digunakan :

Tabel 4.1.

Statistik Deskriptif Variabel

Independen

Descriptive Statistics

\begin{tabular}{|l|r|r|r|r|c|}
\hline & $\mathrm{N}$ & $\begin{array}{c}\text { Minimu } \\
\mathrm{m}\end{array}$ & $\begin{array}{c}\text { Maximu } \\
\mathrm{m}\end{array}$ & Mean & $\begin{array}{c}\text { Std. } \\
\text { Deviation }\end{array}$ \\
\hline Pertumbuhan & 84 & -402.96 & 160.96 & 15.22 & 55.01503 \\
Perusahaan & & & & & \\
Profitabilitas & 84 & -1.11 & 3.44 & 1.225 & .71640 \\
5 & & & \\
Ukuran & 84 & 120344 & $6 . \mathrm{E} 8$ & $9.42 \mathrm{E}$ & $1.256 \mathrm{E} 8$ \\
7 & 3 & & 1.360 & 1.46254 \\
Perusahaan & & & 14.55 & 1 & \\
Likuiditas & 84 & .94 & & & \\
Valid N (listwise) & 84 & & & & \\
\hline
\end{tabular}

Berdasarkan hasil di atas dapat

dijelaskan sebagai berikut :

1. Variable Pertumbuhan Perusahaan diperoleh nilai minimum sebesar $\quad-402,96$ dan nilai maksimum sebesar 
160,96 dengan pertumbuhan perusahaan rata-rata sebesar 15.22. Ini menunjukkan perusahaan selama periode pengamatan ada perusahaan yang mengalami pertumbuhan yang negative dan ada perusahaan yang mengalami pertumbuhan positif, dengan rata-rata pertumbuhan sebesar 15.22.

2. Variable Profitabilitas diperoleh nilai minimum sebesar -1.11 dan nilai maksimum sebesar 3.44 dengan profitabilitas rata-rata sebesar $\quad 1.22$. Ini menunjukkan selama periode pengamatan ada perusahaan profitabilitasnya negative dan ada perusahaan yang profitabiltasnya positif dengan profitabilitas ratarata sebesar 1.22.

3. Variable Ukuran Perusahaan diperoleh nilai minimum sebesar 1,2 trilyun rupiah dan nilai maksimum sebesar 635 trilyun rupiah dengan ukuran perusahaan rata-rata sebesar
9,4 trilyun rupiah. Ini menunjukkan variasi yang cukup besar dalam ukuran perusahaan menjadi sampel penelitian ini. Artinya ada perusahaan perbankan yang berukuran kecil da nada perusahaan perbankan yang berukuran besar.

4. Variabel Likuiditas diperoleh nilai minimum sebesar 0.94 dan nilai makssimum sebesar 14.55 dengan nilai rata-rata sebesar $\quad 1.36$ Ini menunjukkan secara keseluruhan dari perusahaan perbankan yang dijadikan Peringkat Obligasi

\begin{tabular}{|ll|r|r|r|r|}
\hline & Frequency & Percent & $\begin{array}{c}\text { Valid } \\
\text { Percent }\end{array}$ & $\begin{array}{c}\text { Cumulative } \\
\text { Percent }\end{array}$ \\
\hline Valid & 0 & 13 & 15.5 & 15.5 & 15.5 \\
& 71 & 84.5 & 84.5 & 100.0 \\
& Total & 84 & 100.0 & 100.0 & \\
\hline
\end{tabular}

sampel mempunyai likuiditas yang porsitif dengan likuiditas rata-rata sebesar 1.36 .

Tabel 4.2.

\section{Frekwensi Peringkat Obligasi}


Berdasarkan hasil di atas dapat dijelaskan bahwa untuk variable peringkat obligasi, dari jumlah sampel yang ada diperoleh 13 Obligasi yang dapat digolongkan dalam Non Invesment Grade atau sebanyak $15.5 \%$ dan sebanyak 71 Obligasi yang dapat digolongkan dalam Invesment Grade atau sebanyak $84.5 \%$.

\subsection{Analisis Logit Model}

Analisis data yang digunakan menggunakan regresi logistic.Penggunaan alat analisi regresi logistic adalah karena variable dependen kategori/ dummy.Variabel dependen dalam penelitian berupa kategori 0 dan 1 , dimana kategori 0 untuk peringkat obligasi non ivestmen grade dan kategori 1 untuk peringkat obligasi investment grade.Regresi Logistik adalah regresi yang digunakan untuk menguji sejauh mana probailitas terjadinya variable dependen dapat diprediksi dengan variable independen. Sebelum regresi logistic dinterpretasikan hasilnya ada beberapa langkah pengujian dari model yang harus dilalui yaitu :

1. Uji G/ Uji keseluruhan model regresi

2. Uji Wald/ Uji Signifikansi tiap tiap parameter

3. Uji Koefisien determinasi

\section{Uji G}

Uji $G$ disebut juga uji $\quad-2$ ln likelihood.Uji ini merupakan pengujian seluruh model yang bertujuan untuk melihat signifikasi model.

Hipotesisnya :

$\mathrm{H} 0: \beta 0=\beta 1=\beta 2=\beta 3=\beta 4=0$

H1 : sekurang-kurangnya terdapat satu $\neq 0$

Statistik pengujian yang digunakan :

$$
G=-2 \ln \left[\frac{\text { likelihood }(\text { Model } B)}{\text { likelihood }(\text { Model } A)}\right]
$$

Model B : model yang terdiri dari konstanta saja

Model A : model yang terdiri dari seluruh variable

$\mathrm{G}$ berdistribusi Chi Kuadrat dengan derajat bebas $\mathrm{p}$ atau $\mathrm{G} \sim \chi \mathrm{p} 2$. H0 ditolak jika $G>\sim \chi p 2 \alpha, p ; \alpha=$ tingkat signifikansi. Atau dengan cara lain, keputusan menolak atau tidak menolak H0 dapat dilakukan dengan 
membandingkan nilai $\alpha$ dengan $\mathrm{p}$ value, bilai $\mathrm{p}$-value $<\alpha$, maka $\mathrm{H} 0$ ditolak. Bila H0 ditolak artinya Model A tersebut signifikan secara statistik pada tingkat signifikansi $\alpha$.

Tabel 4.3.

\section{Hasil Uji G}

Hasil perbandingan nilai $\mathrm{p}$ value dengan $\alpha=0.05$ menunjukkan bahwa nilai $\mathrm{p}$-value $=0.000$ lebih kecil dari nilai $\alpha=0.05$ sehingga dapat disimpulkan bahwa Model A, yaitu model yang terdiri dari seluruh variable signifikan secara statistik atau model secara keseluruhan dapat memprediksi peringkat obligasi..

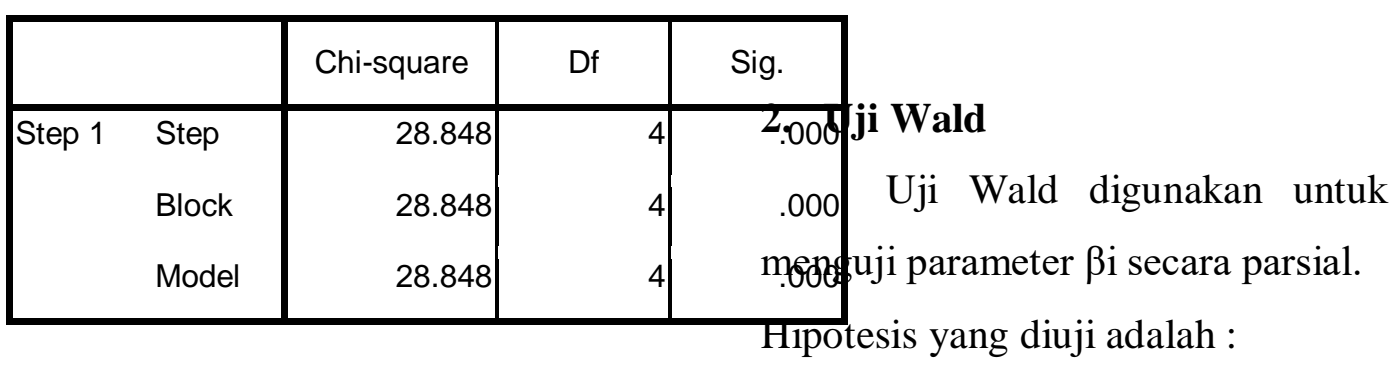

Nilai statistik $G$ dari perhitungan diperoleh sebesar 28.848. Jika dibandingkan dengan nilai kritis pada Tebel Chi Kuadrat dengan $\alpha=0.05$ df 84-5 = 79.08 maka diperoleh hasil bahwa nilai $G$ lebih kecil dari nilai kritis pada table Chi Kuadrat sehingga H0 ditolak dan dapat disimpulkan bahwa Model A, yaitu model yang terdiri dari seluruh variable signifikan secara statistik atau model secara keseluruhan dapat memprediksi peringkat obligasi
$\mathrm{HO}: \beta \mathrm{i}=0$

$\mathrm{H} 1: \beta \mathrm{i} \neq 0$

Formula untuk statistik Wald adalah

$$
W=\frac{\beta_{i}}{S E\left(\hat{\beta}_{i}\right)}
$$

Secara teori statistik uji Wald mengikuti sebaran normal baku jika H0 benar. Kriteria keputusan adalah H0 ditolak jika IWI $>\mathrm{Z}_{\alpha / 2}$.

Tabel 4.4.

\section{Hasil Estimasi Model Logit}




\begin{tabular}{|c|c|c|c|c|c|c|c|}
\hline & & B & S.E. & Wald & Df & Sig. & $\operatorname{Exp}(B)$ \\
\hline Step $1^{a}$ & $\begin{array}{l}\text { PertPer } \\
\text { ush } \\
\text { Profitab } \\
\text { ilitas } \\
\text { UkrPer } \\
\text { ush } \\
\text { CasRat } \\
\text { io } \\
\text { Consta } \\
\text { nt }\end{array}$ & $\begin{array}{l}1.558 \\
.000\end{array}$ & $\begin{array}{l}3.082 \\
4.042\end{array}$ & $\begin{array}{l}5.414 \\
4.738\end{array}$ & 1 & $\begin{array}{l}.029 \\
.185 \\
.114\end{array}$ & $\begin{array}{r}1.008 \\
4.748 \\
1.000 \\
59.695\end{array}$ \\
\hline
\end{tabular}

a. Variable(s) entered on step 1: PertPerush, Profitabilitas, UkrPerush, CasRatio.

Dari hasil perhitungan diperoleh nilai statistik Wald untuk variable Pertumbuhan perusahaan sbesar 1.272, variable Profitabilitas sebesar 5.414, variable Ukuran Perusahaan 4.738, Varianel Likuiditas/ Cash Ratio sebesar 1.760. Sedangkan nilai kritis Tabel Chi Kuadrat pada $\alpha=5 \%$ dan $\mathrm{df}=1$ sebesar 3.84 dan pada $\alpha=$
$10 \%$ dan $\mathrm{df}=1$ sebesar 2.71. Dengan membandingkan hasil perhitungan dengan nilai kritis nya dapat disimpulkan bahwa Variabel Profitabilitas dan Ukuran Perusahaan yang signifikan secara statistik dan untuk Variabel Pertumbuhan Perusahaan dan Likuiditas 
Perusahaan tidak signifikan secara statistik.

variasi variable beban dalam

\section{Uji Koefisien Determinasi}

Pengujian koefisien determinasi menjelaskan variasi variable terikatnya. Dalam model Logit pungujian koefisien determinasi digunakan untuk melihat besar mengunakan Nagelkerke R Square.

\section{Tabel 4.5.}

\section{Hasil Uji Koefisien Determinasi}

\begin{tabular}{|c|c|c|c|}
\hline \multicolumn{4}{|c|}{ Model Summary } \\
\hline Step & -2 Log likelihood & $\begin{array}{c}\text { Cox \& Snell R } \\
\text { Square }\end{array}$ & $\begin{array}{c}\text { Nagelkerke R } \\
\text { Square }\end{array}$ \\
\hline 1 & $43.540^{a}$ & .291 & .503 \\
\hline
\end{tabular}

Hasil perhitungan diperoleh hasil Nagelkerke R Square sebesar 0.50. Ini menunjukkan bahwa variabel independen yang ada dalam model penelitian mampu menjelaskan keragaman data pada variabel rating obligasi sebesar $50 \%$ sedangkan sisanya sebesar $50 \%$ dijelaskan oleh variabel lain di luar model penelitian.

\section{Uji Goodness of Fit/ Uji}

\section{Hosmer and Lemeshow}

Hosmer and Lemeshow Test adalah uji Goodness of fit test (GoF), yaitu uji untuk menentukan apakah model yang

\begin{abstract}
dibentuk sudah tepat atau tidak.Dikatakan tepat apabila tidak ada perbedaan signifikan antara model dengan nilai observasinya.
\end{abstract}

Hipotesis :

H0 $:$ Model $=$ Nilai Observasi
Ha $:$ Model $\neq$ Nilai Observasi

Tabel. 4.6.

Hasil Uji Goodness of Fit

Hosmer and Lemeshow Test

\begin{tabular}{|l|r|r|r|}
\hline Step & Chi-square & df & \multicolumn{1}{c|}{ Sig. } \\
\hline 1 & 4.472 & & 8 \\
\hline
\end{tabular}


Nilai Chi Kuadrat tabel untuk DF 8 (Jumlah variabel independen - 1) pada taraf signifikansi 0,05 adalah sebesar 15.51. Karena nilai Chi Kuadrat Hosmer and Lemeshow hitung 4.472< Chi Kuadrat table 15.51 atau nilai signifikansi sebesar 0.812>0,05 sehingga H0 diterima sehingga secara statistik tidak terdapat perbedaan yang signifikan antara model dengan nilai observasidan model sudah fit dengan data.

\subsubsection{Interpretasi Hasil Regresi Logit}

Setelah serangkaian pengujian terhadap model Logit dilakukan dan diperoleh hasil bahwa model layak untuk dikatakan bahwa model yang baik maka saatnya untuk melakukan interpretasi hasil dari estimasi yang dilakukan terhadap model.

Hasil estimasi model logit yang dilakukan diperoleh persamaan sebagai berikut :

Tabel 4.7.

\section{Hasil Estimasi Model Logit}

Variables in the Equation

\begin{tabular}{|ll|r|r|r|r|r|r|}
\hline & \multicolumn{1}{c|}{ B } & S.E. & Wald & df & Sig. & Exp(B) \\
\hline Step $1^{\mathrm{a}}$ & PertPerush & .008 & .007 & 1.272 & 1 & .259 & 1.008 \\
& Profitabilitas & 1.558 & .669 & 5.414 & 1 & .020 & 4.748 \\
& .000 & .000 & 4.738 & 1 & .029 & 1.000 \\
UkrPerush & 4.089 & 3.082 & 1.760 & 1 & .185 & 59.695 \\
CasRatio & -6.382 & 4.042 & 2.493 & 1 & .114 & .002 \\
Constant & & & 1 & 1 & \\
\hline
\end{tabular}

a. Variable(s) entered on step 1: PertPerush, Profitabilitas, UkrPerush, CasRatio. 


$$
\begin{aligned}
\operatorname{Ln} \frac{P\left(x_{i}\right)}{1-P\left(x_{i}\right)} & =-6.382+0.008 \text { Pertumbuhan Perusahaan } \\
& +1.558 \text { Proftabilitas }+0.0001 \text { Ukuran Perusahaan } \\
& +4.089 \text { Likuiditas }
\end{aligned}
$$

1-P(xi) adalah peluang Obligasi masuk kategori Non Invesment Grade, sebagai kebalikan dari P(xi) sebagai peluang Obligasi masuk kategori Invesment Grade. Oleh karenanya, $\ln [\mathrm{P}(\mathrm{xi}) / 1-\mathrm{P}(\mathrm{xi})]$ secara sederhana merupakan log dari perbandingan antara peluang peluang Obligasi masuk kategori Invesment Grade dengan peluang peluang Obligasi masuk kategori Non Invesment Grade. Oleh karenanya juga, koefisien dalam persamaan ini menunjukkan pengaruh dari Pertumbuhan Perusahaan, Profitabilitas, Ukuran Perusahaan dan Likuiditas terhadap peluang relative Obligasi masuk kategori Invesment Grade yang dibandingkan dengan peluang Obligasi masuk kategori Non Investment Grade.

Uji Wald/ Uji parameter parsial yang sudah dilakukan di atas menunjukkan bahwa hanya variable Profitabilitas dan variable Ukuran perusahaan yang secara statistik berpengaruh secara signifikan.Selanjutnya Koefisien regresi dalam model logit menunjukkan perubahan dalam logit sebagai akibat perubahan satu satuan variabel independent.Interpretasi yang tepat untuk koefisien ini tentunya tergantung pada kemampuan menempatkan arti dari perbedaan antara dua logit. Oleh karenanya, dalam model logit, dikembangkan pengukuran yang dikenal dengan nama odds ratio $(\psi)$. Odds ratio untuk masing-masing variabel ditampilkan oleh SPSS sebagaimana yang terlihat tabel 4.7 diatas (kolom $\operatorname{Exp}(\mathrm{B})$ ). Odds ratio dapat dirumuskan: $\psi=\mathrm{e} \beta$, dimana e adalah bilangan 2,71828 dan $\beta$ 
adalah koefisien masing-masing variabel.

Dari Tabel di atas dapat dilihat bahwa nilai odds ratio untuk variable Profitabilitas sebesar 4.748 dapat diartikan bahwa perusahaan dengan rasio profitabilitas yang lebih tinggi 1 persen peluang obligasinya masuk kategori investment grade adalah 4.748 kali dibandingkan perusahaan dengan rasio profitabilitas yang lebih rendah (1 persen), jika Pertumbuhan Perusahaan, Ukuran Perusahaan dan Likuiditas mereka sama. Artinya Perusahaan dengan Profitailitas yang lebih tinggi memiliki peluang yang lebih tinggi Obligasinya masuk kategori Investment Grade. Sedangkan untuk variable Ukuran Perusahaan, nilai Odds ratio sebesar 1.00 sehingga dapat diartikan dapat diartikan bahwa perusahaan dengan ukuran perusahaan yang lebih besar 1 juta Rupiah peluang obligasinya masuk kategori investment grade adalah 1.00 kali lebih besar dibandingkan perusahaan dengan ukuran perusahaan yang lebih rendah (1 juta Rupiah), jika Pertumbuhan Perusahaan, Profitabilitas dan Likuiditas mereka sama. Artinya Perusahaan dengan Ukuran perusahaan yang lebih besar memiliki peluang yang lebih tinggi Obligasinya masuk kategori Investment Grade.

Selanjutnya, dalam konteks variabel Pertumbuhan Perusahaan, bahwa dari uji wald menunjukkan hasil secara statistik tidak berpengaruh signifikan. Artinya, peluang oblogasi perusahaan masuk kategori investment grade antara perusahaan dengan pertumbuhan tinggi dan perusahaan dengan pertumbuhan rendah adalah sama. Demikian juga untuk variable Likuiditas, bahwa dari uji wald menunjukkan hasil secara statistik tidak berpengaruh signifikan. Artinya, peluang oblogasi perusahaan masuk kategori investment grade antara perusahaan dengan rasio likuiditas tinggi dan perusahaan dengan rasio likuiditas rendah adalah sama.

\section{KESIMPULAN}


Penelitian ini menguji apakah model Logit dapat digunakan untuk melakukan prediksi peringkat obligasi apakah peringkat obligasi suatu perusahaan masuk dalam kategori invesmnet grade atau non investment grade. Dengan menggunakan 4 variable independen yaitu Pertumbuhan Perusahaan, Profitabilitas, Ukuran Perusahaan dan Likuiditas Perusahaan dan menggunakan 84 observasi yang dihasilkan dari 11 sampel penerbitan obligasi perusahaan perbankan periode 2007-2013 maka penelitian ini dapat memberikan bukti empiris sebagai berikut :

1. Uji $G$ atau Uji Keseluruhan Model Logit memberikan hasil yang memuaskan dimana Model Logit yang digunakan secara keseluruhan dapat digunakan untuk memprediksi peringkat obligasi perusahaan.

2. Uji Wald atau Uji parameter parsial menunjukkan bahwa secara parsial hanya dua variable dari empat variable dalam model yang secara parsial berpengaruh secara statistik terhadap variable dependennya.

3. Uji Koefisien Determinasi. Uji Koefisien determinasi dengan menggunakan Nagelkerke $\mathrm{R}$ Square diperoleh hasil yang bagus dimana bahwa variabel independen yang ada dalam model penelitian mampu menjelaskan keragaman data pada variabel rating obligasi sebesar $50 \%$ sedangkan sisanya sebesar 50\% dijelaskan oleh variabel lain di luar model penelitian.

4. Uji Godness of Fit atau uji ketepatan model menunjukkan hasil yang memuaskan dari pengujian yang dilakukan secara statistik tidak terdapat perbedaan yang signifikan antara model dengan nilai observasidan model sudah fit dengan data.

5. Hasil estimasi Model Logit diperoleh hasil bahwa perusahaan dengan rasio proditabilitas yang lebih tinggi 
memilki peluang yang lebih tinggi obligasinya masuk dalam kategori investment grade, dibandingkan dengan perusahaan dengan profitabilitas yang lebih rendah dan jika pertumbuhan perusahaan, ukuran perusahaan dan likuiditas mereka sama.

6. Hasil estimasi Model Logit diperoleh hasil bahwa perusahan dengan ukuran perusahaan yang lebih besar maka memiliki peluang yang lebih besar obligasinya masuk dalam kategori investment grade dibandingkan dengan perusahaan dengan ukuran yang lebih kecil, jika pertumbuhan perusahaan, profitabilitas dan likuiditas mereka sama.

7. Hasil estimasi Logit juga diperoleh hasil bahwa peluang obligasi masuk kategori investment grade untuk perusahaan dengan pertumbuhan tinggi maupun rendah adalah sama.
8. Demikian juga peluang obligasi masuk kategori investment grade untuk perusahaan dengan likuiditas tinggi maupun rendah adalah sama.

\section{DAFTAR PUSTAKA}

Gujarati, 2003, Dasar-Dasar Ekonometrika, Penerbit Salemba, Jakarta

Hartono, Jogiyanto, Prof, Dr, MBA, AK, 2014, Teori Portofoli dan Analisis Investasi, BPFE, Yogyakarta.

Luciana Spica, Amalia dan Vieka, Devi, 2007, Faktor-Faktor yang mempengaruhi prediksi peringkat obligasi pada perusahaan manufaktur yang terdaftar di Bursa Efek Jakarta, Proceeding : Seminar Nasional Manajemen SMART, 3 November, Jakarta

Ninik, Amalia, 2013, Pemeringkatan Obligasi PT. PEFINDO: 
Berdasarkan Informasi

Keuangan, Accounting

Analysis Journal, Januari.

Setyaningtyas, Pratiwi, 2014, Analisi

Faktor-Faktor yang

Mempengaruhi Prediksi

Peringkat

Obligasi

Perbankan yang Terdaftar di

Bursa Efek Indonesia,

Skripsi. Tidak

dipublikasikan. 